\title{
Prevalence of antibodies to Encephalitozoon cuniculi in European hares (Lepus europaeus)
}

\author{
Eva Bártová', Jiřina Marková', Kamil Sedlák² \\ ${ }^{1}$ Department of Biology and Wildlife Diseases, Faculty of Veterinary Hygiene and Ecology, University of Veterinary and \\ Pharmaceutical Sciences Brno, Czech Republic \\ 2 Department of Virology and Serology, State Veterinary Institute Prague, Czech Republic
}

Bártová E, Marková J, Sedlák K. Prevalence of antibodies to Encephalitozoon cuniculi in European hares (Lepus europaeus). Ann Agric Environ Med. 2015; 22(4): 674-676. doi: 10.5604/12321966.1185773

\begin{abstract}
Introduction and objectives. Encephalitozoon cuniculi is an obligate intracellular parasite infecting especially domestic rabbits; however, spontaneous infections have been documented in other mammalian species such as dogs, cats, rabbits, horses, cows and sheep all over the world. Encephalitozoonosis is a chronic and latent disease leading to renal failure, encephalitis, disorders of brain and urinary tract, and may lead to death. There are limited reports on encephalitozoonosis in wildlife, which is why the aim of this study was to detect the prevalence of antibodies to E. cuniculi in European hares.

Materials and methods. Samples of blood sera from 701 wild hares from the Czech Republic $(n=245)$, the Slovak Republic $(n=211)$ and Austria $(n=245)$ were examined by indirect immunofluorescence antibody test (IFAT); samples with titer $\geq 40$ were marked as positive.

Results. The total seroprevalence of E. cuniculi antibodies was $1.42 \%$ with titres in the range $40-640$. Antibodies to E. cuniculi were detected in $2.9 \%$ (7/245), $0.8 \%$ (2/245) and 0.47\% (1/211) hares from the Czech Republic, Austria and the Slovak Republic, respectively.

Conclusions. This is the first detection of antibodies to $E$. cuniculi in hares from Europe showing that hares could be exposed to E. cuniculi infection, however with a low rate.
\end{abstract}

\section{Key words}

encephalitozoonosis, serological examinations, IFAT, Czech Republic

\section{INTRODUCTION AND OBJECTIVE}

Encephalitozoon cuniculi was first identified in a group of laboratory rabbits in 1922 and currently is considered a zoonotic parasite [1]. The most frequently infected animals are domestic rabbits [2]; however, spontaneous infections have been documented in other mammalian species [1]. Encephalitozoonosis is a chronic and latent disease leading to renal failure, encephalitis, disorders of brain and urinary tract and may lead to death [3]. The first description of encephalitozoonosis in European hare (Lepus europeus) was in 2007 in Belgium when E. intestinalis and E. hellem were diagnosed in the kidneys of an adult free-ranging hare, with multifocal wedge-shaped chronic interstitial nephritis. Fresh kidney tissue was examined by real-time PCR and microarray [4]. In Europe, antibodies to E. cuniculi have been detected in various groups of domestic and wildlife animals, but not yet in hares. This was the reason why the aim of this study was to detect antibodies to E. cuniculi in European hares from the Czech Republic, the Slovak Republic and Austria.

\section{MATERIALS AND METHOD}

Hares. Blood sera from 701 wild European hares (Lepus europaeus) were serologicaly examined to determine specific Encephalitozoon cuniculi antibodies. These samples were

Address for correspondence: Eva Bártová, Department of Biology and Wildlife Diseases, Faculty of Veterinary Hygiene and Ecology, University of Veterinary and Pharmaceutical Sciences Brno, Palackého tř. 1/3, Brno, Czech Republic

E-mail: bartovae@vfu.cz

Received: 03 May 2015; accepted: 27 May 2015 collected in the Czech Republic $(\mathrm{n}=245)$ from November 2004 - December 2005 in the regions of the Central Bohemia, South Moravia and Olomouc; in the Slovak Republic $(n=211)$ from November 2006 - March 2007 in the district of Nitra; and in Austria $(n=245)$ from October - December 2005 in the federal states of Lower Austria, Salzburg and Tyrol. All the hare were without apparent clinical signs and their blood was withdrawn by hunters and veterinarians from the hearts. The sera were examined in the State Veterinary Institute, Prague, the Czech Republic.

Serology. The sera were tested by the indirect immunofluorescence antibody test (IFAT) using the commercial set MegaScreen Fluoencephalitozoon c. (Megacor Diagnostic, Hörbranz, Austria) containing positive and negative controls (rabbit serum) and anti-rabbit FITC conjugate. The sera were tested with the basic dilution 1:40; the samples with titres $\geq 40$ were considered positive. The slides were examined under immunofluorescent microscope. In case of positive samples, the green fluorescence was visible in the microscope; if there was a red colouration of antigen (spores of E. cuniculi), the sample was considered negative.

\section{RESULTS}

701 samples of blood sera from hares were used for serological examination. Antibodies to E. cuniculi were detected in $10(1.42 \%)$ hares with prevalence $2.9 \%$ (7/245), 0.8\% (2/245) and $0.5 \%(1 / 211)$ in hares from the Czech Republic, Austria and the Slovak Republic, respectively. The titres of E. cuniculi were detected in the range 40-640 (Tab. 1). 
Table 1. Seroprevalence and titres of Encephalitozoon cuniculi in European hares examined by indirect immunofluorescence antibody test (IFAT)

\begin{tabular}{|c|c|c|c|c|c|c|}
\hline \multirow{2}{*}{ Country } & \multirow{2}{*}{$\begin{array}{l}\text { Positive/total } \\
\text { samples (\%) }\end{array}$} & \multicolumn{5}{|c|}{ IFAT (titre) } \\
\hline & & 40 & 80 & 160 & 320 & 640 \\
\hline Czech Republic & $7 / 245$ (2.9\%) & 1 & 5 & 1 & - & - \\
\hline Slovak Republic & $1 / 211(0.5 \%)$ & - & - & 1 & - & - \\
\hline Austria & $2 / 245(0.8 \%)$ & - & - & - & 1 & 1 \\
\hline Total & $10 / 701(1.42 \%)$ & 1 & 5 & 2 & 1 & 1 \\
\hline
\end{tabular}

\section{DISCUSSION}

Encephalitozoon cuniculi is a parasite that primarily infects rabbits [5]. After infection, the specific antibodies to E. cuniculi could be detected by serological methods; these antibodies remain in the animals throughout their lifetime [3]. Except in rabbits and other domestic animals, antibodies to E. cuniculi were also detected in wildlife and zoo animals [6]. In 2007, E. intestinalis and E. hellem were diagnosed in the kidneys of a free-ranging European hare (Lepus europaeus) in Belgium [4]. The hare was one of five which were found dead in the same area during one month. The visible kidney lesions were similar to lesions caused by E. cuniculi in rabbits; nevertheless, by using methods of molecular biology the pathogens were determined as E. intestinalis and E. hellem.

In the presented study, 701 samples of blood sera from hares were used for serological examination. This is the first detection of E. cuniculi antibodies in hares. Therefore, the presented results can be compared with similar studies perfomed in European rabbits (Oryctolagus cuniculus) belonging to the same order Lagomorpha. For example, the seroprevalence $24.7 \%(20 / 81)$ was detected by IFAT in wild rabbits in Australia [7], 44.7\% (21/47), in wild rabbits from the Slovak Republic tested by ELISA [8], and 3.9\% (8/204) in wild rabbits from France tested by IFAT [9].

During 1993-2012, several seroprevalence studies were performed in various groups of animals from the Czech Republic. The serological prevalence in domestic animals was much higher than the prevalence in hares from the current study. One explanation for this may be the fact that domestic animals could be more often in contact with rabbits which are the primary hosts of E. cuniculi. Rodents also play an important role in spreading this infection because they can contaminate the water and food with E. cuniculi spores. In the Czech Republic, a high prevalence of E. cuniculi antibodies was found in laboratory animals, such as guinea pig, Syrian golden hamster and rat [10]. E. cuniculi was also determined in wild animals, the European otter (Lutra lutra), stone marten (Martes foina) [11], and wild mouse (Mus musculus musculus, M. m. domesticus) [12]. Hares may be primarily infected by the ingestion of food and water contaminated with E. cuniculi spores, and when they become prey for foxes or other carnivores, encephalitozoonosis can spread through other wild animals.

In the Slovak Republic, the situation is similar to that in the Czech Republic. According to the results of serological studies carried out ins 1996-2010, much higher prevalences were also detected in domestic and other wildlife animals than in hares from the current study. For example, E. cuniculi antibodies were detected in $4.4 \%$ of wild boars [13].
In Austria, there are no seroprevalence studies, E. cuniculi was determined by PCR in 6\% (16/268) of voles (Microtus arvalis) and in 7\% (6/86) of European water voles (Arvicola terrestris) [14]; other groups of wild animals have not yet been examined in this country.

E. cuniculi antibodies were detected in 0-95\% [10], 32.4\%, and $68 \%$ [5] laboratory and pet rabbits from the Czech Republic, in 100\% [15], 41.7\% [16] and 21.3\% [8] of domestic rabbits from the Slovak Republic, and in $37 \%$ and $78.3 \%$ of pet rabbits from Austria [17].

Encephalitozoonosis is an important zoonosis, antibodies to E. cuniculi were found also in humans from the Czech and Slovak Republics. Immunocompromised people, such as HIV positive patients, alcoholics and intravenous drug abusers are a risk group [18], however, antibodies to this parasite were found also in a healthy population [19]. Humans may be infected by the ingestion of food and water contaminated with spores of this parasite, [1] but it is possible that there are other ways of infection. In humans, E. cuniculi may affect the nervous and respiratory system, digestive tract, kidneys, and also the endocrine and lymphatic systems [20,21] with diarrhoea, pneumonitis, urinary tract infection and systemic diseases described among immunodeficient patients [21, 22]. The infection in a healthy population is mostly without clinical signs.

In other European countries, antibodies to E. cuniculi were detected in $7.5 \%-85 \%$ of pet rabbits from Switzerland [3], $31.6 \%$ pet and $67.2 \%$ of farm rabbits from Italy $[23,24]$, and in $52 \%$ of domestic rabbits from the United Kingdom [25]. The results of serological examinations may be variable due to many factors, such as the number of animals, gender, and their age, because the risk of infection increases with the age of the animals [23]. In the case of hares and other wildlife, it is important whether they live in a rural or urban environment; it can also be affected by the climate and geographic location.

For future research, it will be convenient to realize some detailed seroprevalence study in hares of different gender, age, from different regions and districts during the different times of year, and analyse the risk factors of this infection.

\section{CONCLUSIONS}

The antibodies to Encephalitozoon cuniculi were detected in blood serum from 701 wild European hares in the Czech Republic, the Slovak Republic and Austria. The total seroprevalence of E. cuniculi antibodies was $1.42 \%$, with titres in the range 40-640. This is the first detection of E. cuniculi antibodies in hares, showing that hares could be exposed to E. cuniculi infection; however, with a low rate.

\section{Acknowledgement}

The authors express their thanks to Prof. František Treml from the University of Veterinary and Pharmaceutical Sciences in Brno, FVM, Department of Infectious Diseases and Microbiology, Brno, and to Ivan Holko from the Tomas Bata University, Faculty of Technology, Department of Food Technology and Microbiology in Zlín for providing the hare sera, and to Dr Barbora Zahradníčková for assistance with sample examination. 


\section{REFERENCES}

1. Jordan CN. Encephalitozoon cuniculi: Diagnostic test and methods of inactivation. Vet Parasitol. 2006; 135: 235-240.

2. Jeklová E, Levá L, Kovařčík K, Matiašovič J, Kummer V, Mašková J, et al. Experimental oral and ocular Encephalitozoon cuniculi infection in rabbits. Parasitol. 2010b; 137: 1749-1757.

3. Deplazes P, Mathis A, Weber R. Epidemiology and zoonotic aspects of Microsporidia of mammals and birds. Contrib Microbiol. 2000; 6: 236-260.

4. De Bosschere H, Wang Z, Orlandi PA. First diagnosis of Encephalitozoon intestinalis and E. Hellem in a European Brown hare (Lepus europaeus) with kidney lesions. Zoonoses Public Health. 2007; 54: 131-134.

5. Jeklová E, Jekl V, Kovařčík K, Hauptman K, Koudela B, Neumayerová $\mathrm{H}$, et al. Usefulness of detection of specific IgM and IgG antibodies for diagnosis of clinical encephalitozoonosis in pet rabbits. Vet Parasitol. 2010a; 170: 143-148.

6. Guscetti F, Mathis A, Hatt JM, Deplazes P. Overt fatal and chronic subclinical Encephalitozoon cuniculi microsporidiosis in a colony of captive emperor tamarins (Saguinus imperator). J Med Primatol. 2003; 32: 111-119.

7. Thomas C, Finn M, Twigg L, Deplazes P, Thompson RCA. Microsporidia (Encephalitozoon cuniculi) in wild rabbits in Australia. Aust Vet J. 1997; 75: 808-810.

8. Bálent $\mathrm{P}$, Halánová M, Sedláková T, Valenčáková A, Čisláková L. Encephalitozoon cuniculi infection in rabbits and laboratory mice in Eastern Slovakia. Bull Vet Inst Pulawy. 2004; 48: 113-116.

9. Künzel F, Joachim A. Encephalitozoonosis in rabbits. Parasitol Res. 2010; 106: 299-309.

10. Chalupský J, Vávra J, Bedrník P. Encephalitozoonosis in laboratory animals - a serological survey. Folia Parasitol. 1979; 26: 1-8.

11. Hůrková L, Modrý D. PCR detection of Neospora caninum, Toxoplasma gondii and Encephalitozoon cuniculi in brains of wild carnivores. Vet Parasitol. 2006; 137: 1-2.

12. Sak B, Kváč M, Květoňová D, Albrecht T, Piálek J. The first report on natural Enterocytozoon bieneusi and Encephalitozoon spp. infections in wild East-European house mice (Mus musculus musculus) and WestEuropean house mice ( $M$. m. domesticus) in a hybrid zone across the Czech Republic-Germany border. Vet Parasitol. 2011; 178: 3-4.

13. Luptáková L, Bálent $\mathrm{P}$, Valenčáková A, Hisira V, Petrovova E. Detection of Toxoplasma gondii and Encephalitozoon spp. in wild boars by serological and molecular methods. Rev Med Vet. 2010; 161: 559-563.
14. Fuehrer HP, Bloschl I, Siehs C, Hassl A. Detection of Toxoplasma gondii, Neospora caninum and Encephalitozoon cuniculi in the brains of common voles (Microtus arvalis) and water voles (Arvicola terrestris) by gene amplification techniques in western Austria (Vorarlberg). Parasitol Res. 2010; 107: 469-473.

15. Levkut M, Levkutová V, Hipíková M, Kolodzieyski L, Bálent P, Bájová V. Demonstration of antibodies to Encephalitozoon cuniculi in rabbits on some Slovak farms. Helminthol. 1996; 33: 25-26.

16. Halánová $M$, Čisláková L, Valenčáková $\mathrm{A}$, Bálent $\mathrm{P}, \mathrm{Adam} J$, Trávníček M. Serological screening of occurrence of antibodies to Encephalitozoon cuniculi in humans and animals in Eastern Slovakia. Ann Agric Environ Med. 2003; 10: 117-120.

17. Künzel F, Gruber A, Tichy A, Edelhofer R, Nell B, Hassan J, et al. Clinical symptoms and diagnosis of encephalitozoonosis in pet rabbits. Vet Parasitol. 2008; 151: 115-124.

18. Kučerová-Pospíšilová Z, Ditrich O. The serological surveillance of several groups of patients using antigens of Encephalitozoon hellem and E. cuniculi antibodies to microsporidia in patients. Folia Parasitol. 1998; 45: 108-112.

19. Sak B, Kváč M, Kučerová Z, Květoňová D, Saková K. Latent microsporidial infection in immunocompetent individuals - a longitudinal study. PLoS Negl Trop Dis. 2011; 5: 1162.

20. Weber R, Bryan RT, Schwartz DA, Owen RL. Human microsporidial infections. Clin Microbiol Rev. 1994; 7: 426-461.

21. Weber R, Deplazes P, Flepp M, Mathis A, Baumann R, Sauer B, et al. Cerebral microsporidiosis due to Encephalitozoon cuniculi in a patient with human immunodeficiency virus infection. N Engl J Med. 1997; 336: 474-478.

22. Deplazes P, Mathis A, Baumgartner R, Tanner I, Weber R. Immunologic and molecular characteristics of encephalitozoon-like microsporidia isolated from humans and rabbits indicate that Encephalitozoon cuniculi is a zoonotic parasite. Clin Inf Dis. 1996; 22: 557-559.

23. Dipineto L, Rinaldi L, Santaniello A, Sensale M, Cuomo A, Calabria M, et al. Serological survey for antibodies to Encephalitozoon cuniculi in pets rabbits in Italy. Zoonoses Public Health. 2008; 55: 173-175.

24. Santaniello A, Dipineto L, Rinaldi L, Menna LF, Cringoli G, Fioretti A. Serological survey of Encephalitozoon cuniculi in farm rabbits in Italy. Res Vet Sci. 2009; 87: 67-69.

25. Keeble EJ, Shaw DJ. Seroprevalence of antibodies to Encephalitozoon cuniculi in domestic rabbits in the United Kingdom. Vet Rec. 2006; 158: $539-544$. 